\title{
IMPACT OF DIVIDEND PER SHARE ON SHARE PRICES OF SELECTED CONSUMER GOODS FIRMS LISTED IN THE NIGERIA STOCK EXCHANGE
}

\author{
Egolum Priscilla U. PhD ${ }^{1^{*}}$ \\ ${ }^{1}$ Department of Accountancy, \\ Nnamdi Azikiwe University, \\ Awka, Anambra State, \\ Nigeria
}

\author{
Onyeogubalu Ogochukwu N.2 \\ ${ }^{2}$ Department of Accountancy, \\ Nnamdi Azikiwe University, \\ Awka, Anambra State, \\ Nigeria
}

\section{* Corresponding Author}

\begin{abstract}
Prospective investors in the Stock Exchange desire empirical based analysis of firms' performance to guide their investment decisions. This study examined the impact of quantitative factor, dividend per share (DPS) on determination of share prices of the selected consumer goods firms listed in the Nigeria Stock Exchange over the period 2009-2018. One hypothesis anchoring on the impact of independent variable DPS on the share prices was formulated for testing in this study. Judgmental sampling technique was adopted in the study. Annual financial statements of the selected firms were used for the study. Ratio analysis, correlation and linear regression models were used to measure the impact of the independent variable on the Share price (SP), the dependent variable. Paired sample t-test was used to test the hypotheses at $5 \%$ level of significance. The empirical findings show that, there is a positive correlation between the independent variable (DPS). DPS is accountable for about $21.7 \%$ changes in the share prices of consumer goods firms listed in the Nigeria Stock Exchange. Investors are enjoined to carefully scrutinize the trend in the DPS of the consumer goods company listed in Nigeria Stock Exchange among other variables before investing their funds; doing so will lead them to making good and viable investment decisions. Management of the consumer goods firms should also strive to operate optimal dividend policy that will not be detrimental to the share price of its organization.
\end{abstract}

KEY WORDS: Dividend per share, share price, Stock Exchange, consumer goods firms.

\section{BACKGROUND TO THE STUDY}

The capital market is a market for securities, where business enterprises and governments can raise long-term funds (Nwude, 2004). The capital markets, which include stock and bond markets, play very important role in nation's economic development by fostering capital formation and economic growth through trading on securities (Nisa and Nishat, 2011). This avenue facilitates coming together of savers and users of capital who through fund pooling and risk sharing grow wealth. Inyiama and Nwoha (2014) stated that firm's financial performance and businesses are influenced by general economic conditions, the performance of the financial markets, inflationary rates, money supply, interest rates, foreign currency exchange rates, changes in laws, regulations and policies of the Central Bank, capital market and other regulators as well as competitive factors on global, federal, state and local government bases. Stock markets promote savings and investments by providing an avenue for portfolio diversification to both individual and corporate investors. Stock markets fuel economic growth through diversification, mobilization and pooling of savings from different parties and availing them to companies for optimal utilization (Kimani and Mutuku, 2013).

Stock Exchange is a place where someone can invest his savings to earn profit. Share price on the other hand, is the price of a single share of a number of saleable stocks of a company; derivative or other 
financial asset of the company. The scope of financial reporting logically presents corporate fundamentals pertaining to an accounting period which are usually harnessed in the computation of accounting ratios. The main accounting ratios which are germane to capital market include earnings per share, dividend per share, price earnings ratio, return on assets, book value per share, net assets per share and dividend cover. Other ratios underscored by capital market watchers include the Tobin's Q and market value to book value ratios (Jang \& Lee, 2010; Oyerinde, 2011; Stephen \& Okoro, 2014; Wula, 2016).

Investments in shares earn investment incomes to the investors and by their nature, they are generally very liquid. The investors can easily trade their ownership of stock and reap capital gains in the process. However, the impact of dividend per share on share prices of consumer goods firms has been of major interest to general public, regulatory authorities, academic communities and investors. Failure of numerous firms had been particularly attributed to the adverse impacts of fluctuations in most of the highlighted accounting ratios/indices given above. Hence, this study analyses a firm's fundamental accounting variable, dividend per share as an integral determinant of the share price of consumer goods firms in the Nigeria Stock Exchange.

Strategically, financial performance analysis involves evaluation of a firm's efficiency and effectiveness in generating revenue by utilizing information contained in the financial statements. Such analysis bares the economic strengths and weaknesses of a firm and helps to establish relationships between various elements of the comprehensive income and financial position of the firm. Share price is an important indicator used by investors to decide whether to invest or not to invest on a particular stock of a given sector. This is because the main objective of investing in the stock market by most investors is to maximize the expected return at low level of risk (Zakaria, Muhammad and Zulkifli, 2012). Earnings information was considered to contain the greatest informational content of all the accounting information because it contains important disclosures concerning the accounting ratios and stock prices (Chang, Chen, Su and Chang 2008). Investors expect to earn a certain rate of return by investing in a firm and any surprises that may cause the realized return to be different from the expected return causes the investors to adjust the stock price so to be able to earn the expected return. Financial managers take corporate finance decisions by considering the price of the firm's stock being traded in the secondary market. This is because investors also incorporate their perception of firm's performance and expectations about future prospects into the stock price by changing the quantity demanded and supplied at a certain price. To adjust these share prices, investors need very sound knowledge of the determinants of share price movements.

Consumer goods sector is a very important sector of any economy. It often contributes up to $60 \%$ in the Gross Domestic Product (GDP) and exports of a nation. This remarkable portion of capital market is indicative of the significance of the sector. Investors are very much interested to purchase the shares from this sector and will seek the opportunity to beat the market as well to earn high return. Nevertheless, share price movement is not easy to predict as there are numerous factors affecting it. Some of the factors are macroeconomic while others are consumer goodsspecific factors. Macroeconomic factors include: interest rate, inflation rate, money supply and exchange rate. Net Asset Value (NAV) per share, Dividend Payout Ratio, Ownership Pattern, Capital Adequacy Ratio (CAR) among others are the firm specific factors which as well influence movements in the price of firms' stock.

Traditionally, dividend represents a portion of profit after tax that is distributed to shareholders for investing and bearing risk in a firm. It is the return that investors (shareholders) receive on their shareholdings and serves as a regular source of income. Investors who prefer current income (in the form of dividend) to capital appreciation, therefore, go for stock that pay out higher dividends. This preference logically causes clamour for such stock and the attendant soaring of their prices. In relative fundamental terms, dividend per share, the ratio of annual dividend amount paid to equity shareholders to number of equity shares outstanding is operationally apt for analysis, hence its adoption in this study. In recent times, capital market dynamics in Nigeria has profoundly induced stock prices swings; visibly featuring random movements that culminate in return slides (Abosede \& Oseni, 2011).

In developed countries many studies have been undertaken to ascertain the determinants of the share price movements, but not much has been done in Nigeria. The present study attempts to investigate the impact of DPS as a determinant of the movements of consumer goods firms' share prices in the Nigeria Stock Exchange.

\subsection{STATEMENT OF THE PROBLEM}

The impact of dividend per share on the returns on stock of consumer goods firms have been of major interest to general public, regulatory authorities, academic communities and investors. Fluctuations in 
this factor impact adversely on stock of firms and can even cause ultimate failure of the firms. It becomes imperative therefore to investigate the sensitivity of the prices of stocks of consumer goods firms in response to variations in dividend per share.

Several studies have been carried out in both developing and developed economies to investigate the relationship between share price and firm performance. The results of the studies are however contradictory. Some found that better firm performance was related to good share price (Srinivasan, 2012; Alumumani, 2014) while some others found a negative relationship between board characteristics and firm's performance (Malhotra and Tandon, 2013). Besides, some other studies could not find any significant relationship between share price and firm performance (Khan \& Amanullah, 2012). These therefore create a gap for studies. The need for this investigation is particularly more in Nigeria where there is paucity of studies that investigated the relationship between share prices and firms' performance.

\subsection{Aim and Objective of the study}

This study aims at examining the impact of dividend per share as a determinant of share prices of selected consumer goods firms listed on the Nigeria Stock Exchange. Specifically, the objective of the study is:

i. To determine the effect of dividend per share on share prices of selected consumer goods firms in Nigeria.

\subsection{Research Question}

In pursuance of the sole objective of this study the following research question was posed:

i. To what extent does dividend per share affect share prices of selected consumer goods firms in Nigeria?

\subsection{Research Hypothesis}

The study formulated and tested the following hypothesis:

$\mathrm{H}_{01}$ : $\quad$ Dividend per share does not significantly affect share prices of selected consumer goods firms in Nigeria.

\subsection{Scope of the Study}

This study focused on the impact of dividend per share as a determinant of share prices of selected consumer goods firms listed in the Nigeria Stock Exchange Market. The Nigeria Stock Exchange has 28 listed consumer goods firms. Purposive sampling technique was used to obtain 10 consumer goods firms which cut across the major subsectors of the consumer goods sector of the stock exchange market. The firms selected are listed in Table A1 presented as Appendix I at the bottom of this article. The study covered a period of ten years spanning 2009 to 2018. This study used dividend per share as independent variable while share price is considered as the dependent variable.

\subsection{REVIEW OF RELATED LITERATURE}

This section presents the conceptual framework which provides the relationship that exists between the variables as found in the reviewed literature. Additionally, both theoretical framework and previous empirical studies in related areas were reviewed and presented here as well. Two theories namely: Fundamental theory and Random theory of share price were considered relevant in the context of this study and were therefore reviewed. Furthermore, two schools of thought namely: the behavioural and the macroeconomist schools of thought perceptions on share pricing were reviewed.

\subsection{Conceptual Review}

\subsubsection{Overview of Share Price}

Share price is the price of a single share out of a number of saleable stocks of a company, derivative or other financial asset. In an ordinary man's reckoning the stock price is the highest amount someone is willing to pay for the stock, or the lowest amount that it can be bought for. The strength and health of any organization culminate in its share price which is considered to be of paramount importance to the organization. Share price of a company's stocks is the biggest concern for the board of directors and the management; if the share price of the company is high or increasing, stakeholders are particularly happy; it shows that the company and its management are doing their jobs excellently. Management of a company with high share price is likely to see a raise and there is very thin probability that they would be fired. On the other hand, if management is unable to create returns for investors, then there is a higher risk that they would be replaced. When share price of a company is low, there is more likelihood of takeover. With takeover old management and board would be sacked. Managers therefore, usually aspire to protect their own interest by working hard to ensure rise or high share prices of their organizations as no one wants to be fired from his job.

In the context of stock markets, financial economists have developed a number of concepts which are known to be essential prerequisites for fulfilling their roles. Among such concepts is dividend per share.

\subsubsection{Dividend Per Share (DPS)}

Dividend is the return that shareholders receive on their shareholdings and is a source of regular income to the investors. A portion of firm's profit is distributed to the shareholders as dividend. Dividend seeking investors who prefer current income in the 
form of dividend to capital appreciation would favour stocks that pay out higher dividends. Their preference for higher dividends paying stocks results in greater demand for such stocks, thereby enhancing their market price. Therefore, dividend is expected to be positively correlated to share price (Nirmala, Sanju and Ramachandran, 2011) As surrogate for dividend, dividend per share is computed as:

$$
\text { DSP }=\frac{\text { Annual Dividend Amount Paid to equity Shareholders }}{\text { Number of Equity or Outstanding Ordinary Shares issued }}
$$

The dividend policy is an important part of corporate financial management policies. This is the policy in which a company takes decision about two things; namely:

(i)

How much of the cash should be retained in the business? For example, for expansion of the business or to repurchase shares; and How much of the cash should be given to the shareholders as dividend?

For a long time, the issue of the dividend policy of the company has captured the interest of many researchers and as a result many theoretical explanations adduced for dividend policy. However, investors prefer companies whose dividend policy is stable; hence companies try to maintain stable dividend payments as they give indications to investors about their strength and stability of their businesses. In developed countries lot of works have been done on dividend policy and its implication on the stock price. However, in developing economies like Nigeria very few studies have been made in this respect. Available studies are mainly in the financial sector. Uddin et al. (2013) used random sampling method to collect data from 62 companies listed on Dhaka Stock Exchange (DSE) and found a significant linear relationship between market price of stock, net asset value per share, dividend percentage and earnings per share. Stephen and Okoro (2014) found that the earnings per share, book value per share and dividend cover are statistically significant in explaining the movement in stock prices. There is therefore need to study the impact of dividend policy and DPS on stock prices of consumer goods sector in Nigeria. Changes occur every day in the business world; hence stock market should be analyzed in line with the changes to provide updated information to investors.

\subsubsection{Consumer Good Firms and Firms' Performance}

Consumer good are goods that are bought and used in satisfaction of human wants such as clothing, food or appliances. Such goods are not utilized in any further production unlike capital goods. On the other hand, performance refers to the accomplishment of a given task as measured against preset standards of accuracy, completeness, cost and speed. In other words, performance is the degree to which an achievement is being or has been accomplished. Financial performance refers to the act of performing financial activity; it is the degree to which financial objective is being or has been accomplished. With regard to firms, financial performance reflects accomplishments of a firm's policies and operations in monetary terms. It is used as indicator of firm's overall financial health over a given period of time. It can also be used to compare similar firms across the same industry or to compare industries or sectors in aggregation. These manifest in the firm's return on investment, return on assets, value added, among others (Mclaughlin, 2019).

\subsection{Theoretical Framework}

\subsubsection{Arbitrage Pricing Theory (APT)}

APT is a model for pricing securities for investors. It comprises common macroeconomic factors that affect share prices. The factors include unexpected changes in inflation, GDP and changes in the yield curve. APT model is flexible as investors can as well select other factors depending on the market; like for oil exporting and importing counties, oil price can be an important factor affecting security prices.

\subsubsection{Fundamental Theory}

According to this theory, share price are determined by certain fundamental factors which factors can be grouped as:

$$
\begin{aligned}
& \text { i. } \quad \text { Company-specific factors } \\
& \text { ii. Industry-relevant information and } \\
& \text { iii. } \quad \text { Macro-economic influences. }
\end{aligned}
$$

At any particular time, any one factor or any combination of the factors may affect the share price of a company. The fundamentalist view the value of a corporation's stock as being determined by expectations regarding future earnings and by the rate at which those earnings are discounted over time. The fundamentalists used the application of present value principles in the valuation of corporate stock, using dividends, earnings, assets and interest rate to establish the price of stock (Lucky, Akani \& Chukwuemeka, 2014).

Based on these fundamental factors, each share has an intrinsic value. At any time in the market, shares may be over-priced or underpriced in relation to its intrinsic value. Generally, the over-priced shares should 
be sold at the earliest opportunity as their prices will fall when their true values are known to the market; conversely, the underpriced shares should be purchased immediately as their prices will go up soon. Constant monitoring and evaluation of shares, in the light of changes in fundamental factors, helps in finding out the over-priced and underpriced shares.

Thus, fundamental analysis helps in finding out the mispriced shares. This kind of analysis comprises:

\section{i. Company analysis \\ ii. Industry analysis and \\ iii. Economic analysis.}

Profit and loss accounts of companies, balance sheets, annual reports, policy statements by the governments, macro-economic reports and such other relevant information are used for fundamental analysis. The main advantage of fundamental analysis is that it involves no assumptions and only the relevant factors are taken into account for analysis. Its main disadvantage is the inaccuracy of information available for analysis. Companies conceal quite a lot of information, making the whole analysis meaningless. Besides, the fundamental analysis cannot predict the random nature of events that affect the share markets.

\subsubsection{Random Walk Theory}

According to random walk theory, share price behave in an independent manner, there is no relationship between the past prices of share and its future price. Hence, the behaviour of prices is largely unpredictable based on their past history. Fama (1970) says the theory of random walks implies that a series of stock price changes has no memory - the past history of the series cannot be used to predict the future in any meaningful way. The future path of the price level of a security is no more predictable than the path of a series of accumulated random numbers. The main thrust of the random walk theory is that the successive price changes of an individual security are independent over time. The prices fluctuate randomly around the intrinsic values of the securities.

The random walk theory is based on the assumption that:

i. The share markets are efficient

ii. There are a large number of active participants competing with each other to predict future prices; and

iii. Information is freely available to all.

In such a market, the price of security at any point in time reflects the effect of information based on all events - past, present as well as future. So the price of a security is considered to be a good estimate of its intrinsic worth. The actions of competing participants in the market cause the actual prices to wander randomly about the intrinsic worth. The intrinsic values themselves can change as a result of new information coming to the market. However, competition will cause the full effect of new information on intrinsic values to be reflected instantaneously in actual prices. The price changes in individual shares are independent and unrelated to the past prices.

\subsubsection{The Behavioural School of Thought}

The behavioural school of finance holds different view from the other schools of thought and opined that market might fail to reflect economic fundamentals under three conditions, which are:

i. $\quad$ The first behavioural condition is irrational behaviour.

This holds that investors behave irrationally when they do not correctly process all the available information while forming their expectations of a company's future performance.

ii. The second is systematic patterns of behaviour

The systematic patterns behavior holds that even if individual investors decided to buy or sell without consulting economic fundamentals, the impact on share prices would be limited.

iii. The third is limits to arbitrage in financial markets

This obtains when investors assume that a company's recent strong performance alone is an indication of future performance; they may start bidding for shares and drive up the price. Some investors might expect a company that surprises the market in one quarter to go on exceeding expectations (Inegbedion, 2009).

\subsubsection{The Macroeconomist School of Thought}

The macroeconomic view adopts the usual method of using factor analysis approach to determine the factors affecting asset returns. Some scholars have used macroeconomic factors to explain stock return and found that changes in interest rate are associated with risk. They interpreted the observation to be a reflection of changes in the rate of inflation; given the finding of Fama (1970) that changes in the rate of inflation are fully reflected in interest rates. The macroeconomic approach attempts to examine the sensitivity of stock prices to changes in macroeconomic variables. The approach posits that stock prices are influenced by changes in money supply, interest rate, inflation and other macroeconomic indicators. It employs a general equilibrium approach, stressing the interrelations between sectors as central to the understanding of the persistence and co-movement of macroeconomic time 
series, based on the economic logic, which suggests that everything does depend on everything else (Iqbal and Mallikarjunappa, 2007).

\subsection{Empirical Review}

Alumumani (2014), used data of listed banks in Amman Stock Exchange over the period of 2005-2011 and showed that there was a positive association between dividend per share, earning per share, size, price earnings ratio and book value and market price of share. Further regression results showed that earning per share, book value, price earnings ratio have significant and positive relationship with market price of share.

Akani and Lucky (2014) examined the relationship between money supply and aggregate stock prices in Nigeria using time series data from $1980-$ 2012, Dickey Fuller Unit Root Test, Engle-granger and Johansen-Joselinus method of co-integration in a Vector Error Correction Model setting. Empirical results demonstrated that there exists a long-run relationship between Currency in Circulation (CC) and Demand Deposit (DD); and the Aggregate Stock Price (ASP), Time Deposit (TD), Savings Deposit (SD) and Net Foreign Assets (NFA) have negative relationship with aggregate stock prices.

Akani (2013) examined the analysis of macroeconomic aggregates on stock prices in Nigeria: application of co-integration and causality tests - 19852011. Dickey Fuller Unit Root Test, Engle-granger and Johansen-Joselius method of co-integration in a Vector Error Correction Model setting were employed. The results show that there exists a long-run equilibrium negative relationship between macroeconomic variables and aggregate stock prices.

Akani and Uzobor (2015) studied empirically the effects of inflation on aggregate stock prices in Nigeria using time series data from 1980 - 2012, Dickey Fuller Unit Root Test, Engle-granger and Johansen-Joselius method of co-integration in a Vector Error Correction Model setting. The result shows that there exists a long-run equilibrium negative relationship between inflation rate and Aggregate Stock Prices. Broad money supply (M2) has a negative and significant effects on aggregates stock prices, Narrow money supply (M1) shows a positive and significant effects on aggregates stock prices while average inflation rate shows a positive and significant relationship between aggregate stock prices.

Sharma (2011) examined the empirical relationship between equity share prices and explanatory variables such as: book value per share, dividend per share, earning per share, price earnings ratio, dividend yield, dividend payout, firm size in terms of sale, and net worth for the period 1993-94 to 2008-09. The results revealed that earning per share, dividend per share, and book value per share have significant impact on the market price of share. Furthermore, results of the study indicated that dividend per share and earnings per share are the strongest determinants of market price, so the results of the study support liberal dividend policy and suggests companies to pay regular dividends.

Uddin, Rahman and Hossain (2013), studied what determines share prices of stock market focusing exclusively on financial sector of Bangladesh. Data were collected from companies like Bank, Insurance and Leasing Companies associated with financial sector ranging from 2005 to 2011 from Dhaka Stock Exchange (DSE). Some pertinent variables like dividend payout (DP), Price earnings ratio (P/E), Net asset value (NAV), Earnings per share (EPS) were selected from previous literature as share price (SP) determinants. A regression model along with some descriptive statistical tools was applied using E-view. Findings show that Earnings per share (EPS), and Price earnings ratio $(\mathrm{P} / \mathrm{E})$ have strong relationship with share prices.

Al- Shubiri (2010) investigated the relationship of microeconomic factors with the stock price by using Simple and Multiple regression analysis. Fourteen commercial banks on Amman Stock Exchange (ASE), for the period of $2005-2008$, were selected for the study. The study found highly positive significant relationship between market price of stock and net asset value per share; market price of stock dividend percentage, gross domestic product. It also found negative significant relationship with inflation and lending interest rate.

AL- Shubiri (2011) investigated the determinants of the dividend policies of the 60 industrial firms listed on ASE for the period of 20052009 and to explain their dividend payments behavior. He used Tobit regression analysis and Logit regression analysis and found that there was a significant effect of Leverage, Institutional Ownership, Profitability, Business Risk, Asset Structure, Growth Opportunities and Firm Size on the dividend payout for the listed firms on Amman Stock Exchange as the determinants of dividends policy as suggested by developed markets.

Khan and Amanullah (2012), investigated the different determinants of share prices and the relationship of these determinants with the share prices of Karachi Stock Exchange (KSE) 100 Index of Pakistan. Five quantitative determinants, namely: Book to Market $(\mathrm{B} / \mathrm{M})$ ratio, Price Earning $(\mathrm{P} / \mathrm{E})$ ratio, Dividend, Gross Domestic Product (GDP), and Interest Rate were selected to find out the direction and strength 
of their relationship. A sample of 34 companies was randomly selected from 34 sectors of KSE. Ten years' (2000-2009) data were collected for the sampled companies. The tools used for analysis are Linear Multiple Regression and Correlation Model. It concluded that all the factors selected have positive and significant relationship with share prices except Interest Rate and $\mathrm{B} / \mathrm{M}$ ratio. The rise in GDP, dividend and $\mathrm{P} / \mathrm{E}$ ratio leads to rise in share prices. $\mathrm{B} / \mathrm{M}$ ratio and interest rate are negatively related to share prices.

Uwuigbe, Olowe, Olusegun, and Godswill (2012), examined the determinants of share prices in the Nigeria Stock Exchange market. A total of 30 firms listed on the Nigeria Stock Exchange market were selected using the judgmental sampling technique. Complementary information for the study were obtained from the Nigerian Stock Exchange fact book and the corporate annual reports of the companies for the period 2006-2010. The paper basically modeled the effects of financial performance, dividend payout, and financial leverage on the share price of listed firms operating in the Nigerian Stock Exchange Market using the regression analysis method. It was found that there exists a significant positive relationship between firms' financial performance and the market value of share prices of the listed firms. Consequently, they concluded that firms' financial performance, dividend payouts and financial leverage are strong determinants of the market value of share prices in Nigeria.

Srinivasan (2012), examined the fundamental determinants of share price in India. The study employed panel data consisting of annual time series data over the period 2006-2011 and cross-section data pertaining to six (6) major sectors of the Indian economy, namely, Heavy and Light Manufacturing, Pharmaceutical, Energy, IT and ITES, Infrastructure, and Banking. The panel data techniques, viz: Fixed Effects model and Random Effects model were employed to investigate the objective. The empirical results revealed that the dividend per share has a negative and significant impact on the share price of manufacturing, pharmaceutical, energy and infrastructure sectors. Earnings per share and priceearnings ratio were found as the crucial determinants of share prices of manufacturing, pharmaceutical, energy, infrastructure, and commercial banking sectors. Size was revealed as a significant factor in determining the share prices of all sectors under consideration except manufacturing. Moreover, the book value per share positively influences the share prices of pharmaceutical, energy, IT and ITES, and Infrastructure.

Malhotra and Tandon (2013) attempted to determine the factors that influence stock prices in the context of National Stock Exchange (NSE) of 100 companies. A sample of 95 companies was selected for the period 2007 - 2012 and linear regression model was used. The results indicated that firms' book value, earning per share, and price-earnings ratio are having a significant positive relationship with firm's stock price while dividend yield is having a significant inverse association with the market price of the firms' stock.

\subsection{RESEARCH METHODOLOGY \\ 3.1 Research Design}

The study employed the ex-post facto research design. An ex-post facto research determines the causeeffect relationship among variables. It seeks to find out the factors that are associated with certain occurrence, conditions, events or behaviours by analyzing past events or already existing data for possible casual factors.

\subsection{Population of the Study}

The population of this study comprises all 26 consumer goods firms on the Daily Official List as at 31st December, 2018. Panel data, representing a combination of time series with cross-sectional submissions over a ten-year period (2009-2018), were harnessed for the study.

\subsection{Sample Size and Sampling Method}

This research adopted a profit - dividend payment filter. Firms that did not make profit or those that made profit but did not declare dividends in the period were excluded. This gave a sample size of ten (10) firms, representing $59 \%$ of the population. This was well accommodated within the framework of Krejcie and Morgan (1970), which stipulates a minimum sample size of $50 \%$ of a defined population to be adopted for the purpose of generalization. By this, every firm in the sample had the same number of observations, giving 100 observations (derived as product of 10 sample firms and ten years).

\subsection{Source of Data}

This study basically made use of secondary data. The data set were sourced from publications of the Nigeria Stock Exchange (NSE) and the annual reports and accounts of the quoted consumer goods firms as well as their respective notes to the accounts.

\subsection{Measurement of Variables}

Variables used in this study include:

i. dependent variable (share price); and

ii. independent variable (dividend per share).

The ratios to be computed would be sourced from individual financial statements of the sampled firms for the study period. Concepts and measurements of the variables are summarized in Table 1: 
ISSN (Online): 2455-3662

EPRA International Journal of Multidisciplinary Research (IJMR) - Peer Reviewed Journal

Volume: 7 | Issue: 3 | March 2021|| Journal D0I: 10.36713/epra2013 || SJIF Impact Factor 2021:7.147 ||ISI Value: 1.188

Table 1: Concepts and Measurements of Variables in the Study

\begin{tabular}{|c|c|c|}
\hline Variables & Definition & Measurements \\
\hline Dependent Variables & Share Price & $\begin{array}{c}\text { Closing share price at the end of the } \\
\text { financial year }\end{array}$ \\
\hline SHP & & \\
\hline Explanatory Variables & Dividend Per Share & $\begin{array}{c}\text { Declared Dividend divided by } \\
\text { Outstanding Ordinary Shares }\end{array}$ \\
\hline DPS
\end{tabular}

\subsection{Method of Data Analysis}

Inferential statistics of the hypotheses was carried out with the aid of E-Views 9.0 Statistical Software. In analyzing the data, the statistical proceedings involve: descriptive statistics, which provide simple summaries about the variables; using coefficient of correlation which determines the degree and direction of association between the variables and also tells us about the strength of relationship and the direction of relationship as well; simple regression analysis, which reveals predictive potential of the variable and makes for functional modelling. The statistical treatment of the research hypothesis involves t-test, which is justified by a sample size less than 30 (Nsude, 2005; Gujarati and Porter, 2009).

\subsection{Model Specification}

An over-arching framework in this regard recognizes the potency of the fundamental variable, dividend per share. Share price is associated, $\mathrm{SP}_{\mathrm{t}}=\mathrm{f}$ $\left(\right.$ Divps $\left._{t} e_{t}\right)$

The model specification for this study would take the following form:

$\mathrm{SHP}_{\mathrm{it}} \quad=\quad \beta_{0}+\beta_{1} \mathrm{DPS}_{\mathrm{it}}+\mu_{\mathrm{it}}-\quad-$

Where:

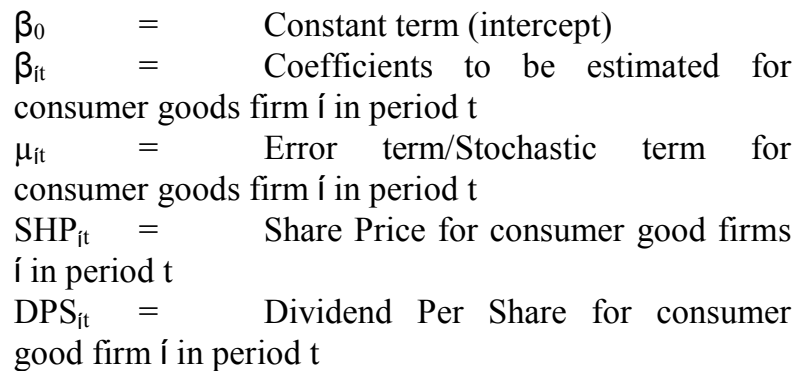

\subsection{Decision Rule}

Reject $\mathrm{H}_{0}$ if the $\mathrm{P}$-value of the test is less than $\alpha$-value (level of significance) which here is at $5 \%$, otherwise accept $\mathrm{H}_{1}$.

\subsection{DATA PRESENTATION AND ANALYSIS}

\subsection{Data Presentation}

The panel data obtained from the publications of the Nigerian Stock Exchange (NSE), fact books, annual reports and accounts of the study consumer goods firms are presented in Table 2:

Table 2 Operational Variables of data

$\begin{array}{cccc}\text { CON. GD } & \text { YEAR } & \text { SP } & \text { DPS } \\ \text { 7-Up } & 2009 & 0.14 & 1.42 \\ \text { 7-Up } & 2010 & 0.21 & 1.22 \\ \text { 7-Up } & 2011 & 0.23 & 1.34 \\ \text { 7-Up } & 2012 & 0.23 & 0.45 \\ \text { 7-Up } & 2013 & 0.11 & 0.49 \\ \text { 7-Up } & 2014 & 0.11 & 0.53 \\ \text { 7-Up } & 2015 & 0.08 & 0.46 \\ \text { 7-Up } & 2016 & 0.08 & 0.98 \\ \text { 7-Up } & 2017 & 0.06 & 0.34 \\ \text { 7-Up } & 2018 & 0.13 & 0.46 \\ \text { Nig. Brew } & 2009 & 0.11 & 0.43\end{array}$




\begin{tabular}{|c|c|c|c|}
\hline Nig. Brew & 2010 & 0.1 & 0.52 \\
\hline Nig. Brew & 2011 & 0.11 & 0.73 \\
\hline Nig. Brew & 2012 & 0.11 & 0.75 \\
\hline Nig. Brew & 2013 & 0.11 & 0.81 \\
\hline Nig. Brew & 2014 & 0.16 & 0.17 \\
\hline Nig. Brew & 2015 & 0.13 & 0.34 \\
\hline Nig. Brew & 2016 & 0.06 & 0.37 \\
\hline Nig. Brew & 2017 & 0.08 & 0.53 \\
\hline Nig. Brew & 2018 & 0.1 & 0.56 \\
\hline Gui. Plc & 2009 & 0.12 & 0.74 \\
\hline Gui. Plc & 2010 & 0.1 & 0.62 \\
\hline Gui. Plc & 2011 & 0.12 & 0.71 \\
\hline Gui. Plc & 2012 & 0.09 & 0.48 \\
\hline Gui. Plc & 2013 & 0.16 & 0.87 \\
\hline Gui. Plc & 2014 & 0.16 & 0.73 \\
\hline Gui. Plc & 2015 & 0.12 & 0.97 \\
\hline Gui. Plc & 2016 & 0.12 & 1.22 \\
\hline Gui. Plc & 2017 & 0.12 & 1.21 \\
\hline Gui. Plc & 2018 & 0.11 & 0.93 \\
\hline Nig. Flour & 2009 & 0.08 & 0.31 \\
\hline Nig. Flour & 2010 & 0.1 & 0.37 \\
\hline Nig. Flour & 2011 & 0.13 & 0.58 \\
\hline Nig. Flour & 2012 & 0.22 & 0.05 \\
\hline Nig. Flour & 2013 & 0.86 & 0.13 \\
\hline Nig. Flour & 2014 & 1.39 & 0.08 \\
\hline Nig. Flour & 2015 & 0.1 & 0.41 \\
\hline Nig. Flour & 2016 & 0.09 & 0.8 \\
\hline Nig. Flour & 2017 & 0.11 & 0.38 \\
\hline Nig. Flour & 2018 & 0.14 & 0.56 \\
\hline Dangote Sugar & 2009 & 0.11 & 0.43 \\
\hline Dangote Sugar & 2010 & 0.13 & 0.63 \\
\hline Dangote Sugar & 2011 & 0.13 & 0.1 \\
\hline Dangote Sugar & 2012 & 0.81 & 0.81 \\
\hline Dangote Sugar & 2013 & 0.05 & 0.05 \\
\hline Dangote Sugar & 2014 & 0.13 & 4.73 \\
\hline Dangote Sugar & 2015 & 0.12 & 5.62 \\
\hline Dangote Sugar & 2016 & 0.1 & 0.41 \\
\hline Dangote Sugar & 2017 & 0.11 & 0.89 \\
\hline Dangote Sugar & 2018 & 0.1 & 0.47 \\
\hline Dangote Flour & 2009 & 0.11 & 0.79 \\
\hline Dangote Flour & 2010 & 0.1 & 0.45 \\
\hline
\end{tabular}




\begin{tabular}{|c|c|c|c|}
\hline Dangote Flour & 2011 & 0.11 & 0.79 \\
\hline Dangote Flour & 2012 & 0.13 & 0.7 \\
\hline Dangote Flour & 2013 & 0.12 & 0.79 \\
\hline Dangote Flour & 2014 & 0.11 & 0.81 \\
\hline Dangote Flour & 2015 & 0.11 & 0.14 \\
\hline Dangote Flour & 2016 & 0.13 & 0.74 \\
\hline Dangote Flour & 2017 & 0.12 & 0.78 \\
\hline Dangote Flour & 2018 & 0.11 & 0.76 \\
\hline Honeywell Flour & 2009 & 0.11 & 0.61 \\
\hline Honeywell Flour & 2010 & 0.11 & 0.74 \\
\hline Honeywell Flour & 2011 & 0.12 & 0.86 \\
\hline Honeywell Flour & 2012 & 0.13 & 0.94 \\
\hline Honeywell Flour & 2013 & 0.13 & 0.98 \\
\hline Honeywell Flour & 2014 & 0.22 & 1.69 \\
\hline Honeywell Flour & 2015 & 0.17 & 1.74 \\
\hline Honeywell Flour & 2016 & 0.18 & 1.37 \\
\hline Honeywell Flour & 2017 & 0.19 & 1.66 \\
\hline Honeywell Flour & 2018 & 0.15 & 1.55 \\
\hline Nestle Nig. Plc & 2009 & 0.1 & 0.19 \\
\hline Nestle Nig. Plc & 2010 & 0.1 & 0.99 \\
\hline Nestle Nig. Plc & 2011 & 0.1 & 0.46 \\
\hline Nestle Nig. Plc & 2012 & 0.15 & 0.8 \\
\hline Nestle Nig. Plc & 2013 & 0.12 & 0.67 \\
\hline Nestle Nig. Plc & 2014 & 0.11 & 0.73 \\
\hline Nestle Nig. Plc & 2015 & 0.1 & 0.58 \\
\hline Nestle Nig. Plc & 2016 & 0.09 & 0.52 \\
\hline Nestle Nig. Plc & 2017 & 0.12 & 0.67 \\
\hline Nestle Nig. Plc & 2018 & 0.15 & 2.76 \\
\hline UTC Nig. Plc & 2009 & 0.1 & 2.27 \\
\hline UTC Nig. Plc & 2010 & 0.11 & 2.08 \\
\hline UTC Nig. Plc & 2011 & 0.12 & 1.72 \\
\hline UTC Nig. Plc & 2012 & 0.11 & 1.23 \\
\hline UTC Nig. Plc & 2013 & 0.1 & 1.31 \\
\hline UTC Nig. Plc & 2014 & 0.1 & 1.81 \\
\hline UTC Nig. Plc & 2015 & 0.01 & 0.06 \\
\hline UTC Nig. Plc & 2016 & 0.11 & 1.01 \\
\hline UTC Nig. Plc & 2017 & 0.16 & 1.17 \\
\hline UTC Nig. Plc & 2018 & 0.11 & 0.84 \\
\hline Unilever Nig. Plc & 2009 & 0.21 & 0.79 \\
\hline Unilever Nig. Plc & 2010 & 0.13 & 0.03 \\
\hline Unilever Nig. Plc & 2011 & 0.12 & 0.22 \\
\hline
\end{tabular}




$\begin{array}{lccc}\text { Unilever Nig. Plc } & 2012 & 0.11 & 0.96 \\ \text { Unilever Nig. Plc } & 2013 & 0.1 & 0.62 \\ \text { Unilever Nig. Plc } & 2014 & 0.09 & 0.8 \\ \text { Unilever Nig. Plc } & 2015 & 0.14 & 1.7 \\ \text { Unilever Nig. Plc } & 2016 & 0.12 & 0.71 \\ \text { Unilever Nig. Plc } & 2017 & 0.1 & 0.84 \\ \text { Unilever Nig. Plc } & 2018 & 0.11 & 0.92\end{array}$

Source: Annual reports and accounts (various issues)

The correlation coefficients of the study variables are given in Table 3 below.

Table 3: Correlation Matrix of the Variables

$\begin{array}{ccc} & \text { SHP } & \text { DPS } \\ \text { SHP } & 1.000 & 0.466 \\ \text { DPS } & 0.466 & 1.000\end{array}$

Source: E-Views 9.0 Correlation Output

The correlation result in Table 3 indicates existence of a positive relationship between DPS (0.466) and SHP.

\subsection{Test of Hypothesis}

$\mathbf{H}_{01}$ : Dividend per share does not significantly affect share price of selected consumer goods firms in Nigeria.
$\mathbf{H}_{11}$ : Dividend per share significantly affects share prices of selected consumer goods firms in Nigeria.

Pursuant to testing the hypothesis, simple regression analysis of the share prices on the dividend per share of the study consumer goods firms and t-test of the statistics were run and the results are presented in Table 4 below.

Table 4: Simple Regression Analysis between SP and DPS of consumer good firms in Nigeria Dependent Variable: SP

Method: Least Squares

Date: 09/23/20 Time: 18:41

Sample: 2009 - 2018

Included observations: 10

\begin{tabular}{lrlrr}
\hline \hline \multicolumn{1}{c}{ Variable } & Coefficien & & \\
\multicolumn{1}{c}{$\mathrm{t}$} & C & Std. Error & t-Statistic & Prob. \\
\hline \hline \multicolumn{1}{c}{ DPS } & 0.083971 & 0.040889 & 2.053637 & 0.0741 \\
& 0.070258 & 0.047142 & 2.490350 & 0.0345 \\
\hline \hline R-squared & 0.217309 & Mean dependent var & 0.138000 \\
Adjusted R-squared & 0.119472 & S.D. dependent var & 0.063736 \\
S.E. of regression & 0.059807 & Akaike info criterion & -2.618525 \\
Sum squared resid & 0.028615 & Schwarz criterion & -2.558008 \\
Log likelihood & 15.09263 & Hannan-Quinn criter. & -2.684913 \\
F-statistic & 4.221143 & Durbin-Watson stat & 1.138439 \\
Prob(F-statistic) & 0.034466 & & \\
\hline \hline
\end{tabular}

Source: E-Views 9.0 Regression Output, 2020 


\subsubsection{Interpretation of Simple Regression Result}

In Table 4, a simple regression analysis was conducted to test the influence of the predictor variable. Adjusted $\mathrm{R}$ squared is coefficient of determination which tells us the variation in the dependent variable due to changes in the independent variable. From the findings in Table 4 above, the value of $\mathrm{R}$ squared was 0.217 , an indication that there was variation of $21.7 \%$ on the performance measure (SHP) due to changes in DPS. This shows that dividend per share of consumer goods firms accounted for $21.7 \%$ changes in the share prices of the firms. The probability of the slope coefficient indicate that; $\mathrm{P}\left(\mathrm{x}_{1}=0.0345<0.05\right)$. This implies that DPS is positively related to SHP, however, significant at $5 \%$. The Durbin-Watson Statistic of 1.138439 suggests that the model does not contain serial correlation problem.

The F-statistic of the DPS regression is equal to 4.221143 and the associated F-statistic probability is equal to 0.034466 , so the null hypothesis was rejected and the alternative hypothesis was accepted. As a result, there is linear relationship between PS to the independent variable (DPS).

\subsubsection{Decision}

The result of the Prob(F-statistic) of 0.034466 is less than the critical value of $5 \%$ (i.e. 0.05 ) significance level leads to the conclusion that dividend per share of consumer goods firms has a significant positive impact on share price at $5 \%$ level of significance.

\subsection{Discussion of Findings}

The empirical finding show that there is a positive correlation between the independent variable DPS and the dependent variable market price of the share of consumer goods firms in listed on the Nigeria Stock Exchange. Dividend per share is an invariable indicator of the operational profitability of a firm. This result is consistent with the results of previous similar studies in other sectors of the economy. For example, Lucky and Nwosi (2015) in investigation of the relationship between commercial banks' asset quality and their stock prices in Nigeria found that a significant positive relationship exists between them. This means that asset quality (via profitability) can positively affect stock price. Consequent upon this revelation management of consumer goods firms in Nigeria must be very cautious with the firm the dividend policy they operate as this can either enhance the company's stock price in the stock exchange market or cause their share to lose value in the stock market.

\subsection{SUMMARY OF FINDINGS, CONCLUSION AND RECOMMENDATIONS}

\subsection{Summary of Findings}

Based on the analysis of the data obtained for this study, the following finding was made:

i. Dividend per share has a significant positive impact on market value of shares of quoted consumer goods firms in Nigeria Stock Exchange at 5\% level of significance.

\subsection{Conclusion}

This study assessed the impact of dividend per share as a determinant of share prices of consumer goods firms using data obtained from annual reports and accounts and publications from Nigeria Stock Exchange for the period spanning from 2009-2018. Based on the results of the empirical analysis, the variable, dividend per share is a significant determinant of share prices for all the consumer good firms under consideration. Hence, the present study confirms that the study of financial factors proved to be beneficial for the investors in Nigeria, as these factors possess strong explanatory power and can therefore be used to make accurate future forecasts of stock prices. Investors should critically analyze the accounting variable, dividend per share, of company before investing in the company.

\subsection{Recommendations}

Following the revelations in this study, the under recommendations were made with the belief that their incorporation in the management strategy will go a long way to ensure high performance of the stock prices in the market.

i. There is need for a large scale study incorporating more microeconomic (internal) and macroeconomic (external) variables for various sectors of the stock market in Nigeria. Such investigations can be extended to cover longer time periods using other multivariate statistical models in the analysis.

ii. There is need for the management of the consumer goods firms to strengthen its efforts in effective management of dividend policy and other micro and the macro prudential variables to avoid their occasioning negative effect on the share prices.

\section{REFERENCES}

1. Abosede, A. J. \& Oseni, J. E. (2011). Theoretical analysis of firm and market-specific proxies of information asymmetry on equity prices in the stock 
markets. Australian Journal of Business and Management Research, 1(2), 1-13.

2. Almumani, M. A. (2014). Determinants of equity share prices of the listed banks in Amman Stock Exchange: Quantitative Approach. International Journal of Business and Social Science, 5(1), 91104.

3. AL-Shubiri, F. (2011). Determinants of Changes Dividend Behavior Policy: Evidence from the Amman Stock Exchange Amman, Arab University Jordan College of Business.

4. AL-Shubiri, F. (2010). Analysis the Determinants of Market Stock Price Movements: An Empirical Study of Jordanian Commercial Banks. International Journal of Business \& Management, 5 (10): 137.

5. Akani, H. W. (2013). Analysis of Macroeconomic Aggregates on Stock prices in Nigeria. An application of Co-integration and causality tests (1985-2011). International Journal of Business and Management Review, 1(3):56-79.

6. Akani, H. W., and Lucky, A.L., (2014). Money Supply and Aggregate Stock Prices in Nigeria: An Analysis of Co-Integration and Causality Tests. Research Journal of Finance, 2 (10), 1-24.

7. Akani, H. W. and Uzobor, C. C. (2015). Empirical Analysis of Effects of inflation on Aggregates Stock prices in Nigeria:1980-2012.European Journal of Accounting, Auditing and Finance Research, 3(9):31-51.

8. Chang, H. L., Chen, Y. S., Su, C.W., \& Chang, Y.W. (2008). The relationship between stock price and EPS: Evidence based on Taiwan panel data. Economic Bulletin, 3(30), 1-12.

9. Fama, E. F. (1970). Efficient Capital Markets: A Review of Theory and empirical Work. Journal of Finance, 25(2), $383-417$.

10. Gujarati, D. N. \& Porter, D. C. (2009). Basic Econometrics. Boston: McGraw-Hill.

11. Inegbedion, H. E., (2009). Efficient Market Hypothesis and the Nigerian Capital Market," an Unpublished M Sc. Thesis written in the Department of Business Administration, University of Benin, Nigeria.

12. Inyiama, O.\& Nwoha, C. (2014). Macroeconomic Variables and Share Price of Nigeria Brewery Industry: Evidence from Nigeria. Breweries Plc. EU Accounting Auditing and Finance Research, 2(5), 19-32.

13. Iqbal \& Mallikarjunappa, T., (2007). Market Reaction to Earnings Information: An Empirical Study. Aims International 1(2) 153-167.

14. Jang, J. I. \& Lee, K. J. (2010). Inter-temporal and cross-sectional variation in the value relevance of earnings and equity book value for Korean firms, PanPacific Journal of Business Research, 1(1), 415.

15. Khan, S. H. (2009). Determinants of share price movements in Bangladesh: Dividends and retained earnings (Unpublished MSc Thesis), School of
Management, Blekinge Institute of Technology, 148.

16. Khan, M., \& Amanullah, (2012). Determinants of Share Prices at Karachi Stock exchange. International Journal of Business \& Management Studies.2012; 4(1): 1309-8047.

17. Kimani, D. K., \& Mutuku, C. M. (2013). Inflation dynamics on the overall stock market performance: The Case of Nairobi Securities Exchange in Kenya. Economics and Finance Review, 2(11): 1-11.

18. Krejcie, R. V. \& Morgan, D. W. (1970). Determining sample size for research activities. Educational and psychological measurement, 30, 607-610.

19. Lucky, A. L., Akani, H. W., \& Chukwuemeka, A. (2014). Prudential Determinants of Stock Prices of Commercial Banks in Nigeria: An Application of Fundamentalists and Macroeconomic View. 1980 2014, IIARD- International Journal of Banking and Finance Research ISSN 2695-186X (1), 8.

20. Lucky, A. L., and Nwosi, A. A. (2015). Asset quality and Profitability of Commercial Banks: Evidence from Nigeria. Research Journal of Finance and Accounting, 6(18),26-34.

21. Malhotra,N., \& Tandon,K. (2013). Determinants of Stock Prices: Empirical Evidence from NSE 100 Companies, IRACST- International Journal of Research in Management \& Technology (IJRMT); 3(3): 86-95.

22. Mclaughlin, L. (2019). How to avoid a layoff. http://www.businessdictionary.com/article/1201/ho w-to-avoid-a-layoffl. Retrieved 28/03/2019

23. Nigerian Stock Exchange (2014). Daily Official List. Abuja, Nigeria

24. Nigerian Stock Exchange (2011/2012). The Nigerian stock exchange Factbook. Abuja, Nigeria:

25. Nirmala, P., Sanju, S., \& Ramachandran, M. (2011). Determinants of Share Prices in India. Journal of Emerging Trends in Economics and Management Sciences (JETEMS). 2 (2): 124-130.

26. Nisa, M. U., \& Nishat, M. (2011). The determinants of stock prices in Pakistan. Asian Economics and Financial Review, 1(4), 276-291.

27. Nsude, F. I. (2005). Fundamental of statistics for business. (2nd ed.). Enugu: CIDJAP.

28. Nwude, C. (2004). Basic Principles of Financial Management-A first Course (Second ed.). EnuguCover Design, Film Set, Arrangement and Printing.

29. Oyerinde, D. T. (2011). Value relevance of accounting (Unpublished PhD Thesis), Covenant University, Ota, Nigeria.

30. Sharma, S. (2011). Determinants of equity share prices in India. Journal of Arts, Science \& Commerce, 2(4), 51-60.

31. Srinivasan, P. (2012). Determinants of equity share prices in India: A panel data approach. The Romanian Economic Journal, 15(46), 205-228.

32. Stephen, E. A. \& Okoro, E. G. (2014). Determinants of stock price movement in Nigeria: Evidence from the Nigerian Stock 
Exchange. Journal of Economics and Sustainable Development, 5(3), 1-7.

33. Uddin, R. D., Rahman, Z. S. M., Hossa, R. Md. (2013). Determinants of Stock Prices in Financial Sector Companies in Bangladesh- A Study on Dhaka Stock Exchange (DSE) Interdisciplinary Journal of Contemporary Research in Business(5)3.

34. Uwuigbe, U., Olusegun, O., \& Godswill, A. (2012). An Assessment of the Determinants of Share Price in Nigeria: A Study of Selected Listed Firms, ACTA Universities Danubius; 8, (6).

35. Wula, J. T. (2016). Effects of financial performance on share price of listed consumer goods firms in Nigeria (Unpublished MSc Thesis). Makurdi, Nigeria: Benue State University.

36. Zakaria, Z., Muhammad, J., \& Zulkifli, A. H. (2012). The impact of dividend policy on the share price volatility. International Journal of Economics and Management Sciences, 2(5), 1-8.

APPENDIX I

Table A1: Listed Firms Selected for the Study

\begin{tabular}{|c|c|c|}
\hline S/NO & NAME OF FIRM & SUB-SECTOR \\
\hline 1. & 7-Up Bottling Company Plc & Beverages Non-Alcoholic \\
\hline 2. & Guinness Nigeria Plc & Beverages Brewers/Distillers \\
\hline 3. & Nigerian Breweries Plc & Beverages Brewers/Distillers \\
\hline 4. & Dangote Sugar Refinery Plc & Food Products \\
\hline 5. & Flour Mills of Nigeria Plc & Food Products \\
\hline 6. & Dangote Flour Mills & Food Products \\
\hline 7. & Nestle Nigeria Plc & Food Products \\
\hline 8. & UTC Nigeria Plc & Personal Household Products \\
\hline 9. & Honeywell Flour Mills Plc & \\
\hline 10. & Unilever Nigeria Plc &
\end{tabular}

